\title{
Isolation and Molecular Identification of an Aerobic Denitrifier
}

\author{
Hongyu Wang, Kai Yang, Bin Ji, and Yu Jiang
}

\begin{abstract}
Six bacteria strains of which total nitrogen removal efficiency is over $\mathbf{7 0 \%}$ were isolated from the activated sludge after enrichment culture. The strain Z31 with higher nitrogen removal was selected and its characteristic of aerobic denitrification was confirmed by the nitrogen element track. The results showed that the nitrate in the culture could be efficiently removed by strain $\mathrm{Z31}$ and the nitrate nitrogen removal rate was up to above $95 \%$. There was obvious nitrite accumulation during the denitrification process. Moreover, medium $\mathrm{pH}$ was increased and medium ORP was decreased as a result of denitrification. According to the morphological observation, physiological biochemical test and sequence analysis of the $16 \mathrm{~S}$ rDNA, strain $\mathrm{Z31}$ was identified as Pseudomonas stutzeri. And the phylogentic position of the strain was performed based on the phylogenetic tree.
\end{abstract}

Index Terms-Aerobic denitrifier, biological nitrogen removal, nitrate wastewater, Pseudomonas stutzeri.

\section{INTRODUCTION}

Nitrogen pollution in water is a worsening problem worldwide. And bio-denitrification is believed to be the most economic and efficient nitrogen removal method [1]. In the traditional biological nitrogen removal process, there are two processes-aerobic nitrification and anoxic denitrification [2]. That is nitrosobacteria oxidize ammonia into nitrite and furthermore nitrobacteria oxidize nitrite into nitrate under aerobic conditions. Then denitrifying bacteria reduce nitrate nitrogen or nitrite nitrogen into $\mathrm{N}_{2}$ or $\mathrm{N}_{2} \mathrm{O}$ under anoxic conditions. Denitrification is always considered to be achieved only in anaerobic or anoxic conditions. But in recent decades, people have found that some bacteria can have nitrate respiration under aerobic conditions, the one known as aerobic denitrification biochemical process has gradually been accepted. Aerobic denitrification was first proposed by Robertson and Kuenen, they observed denitrification happened under the conditions of existence of oxygen [3]. Aerobic denitrifiers have been found in foreign countries such as Thiosphaera Pantotropha, Alcaligenes faecalis, Pseudomonas nautical,Thaurea mechernichensis and Microvirgula aerodenitrificans, and so on [4]-[9].

The emergence of aerobic denitrifiers makes it to be possible to complete nitrification and denitrification simultaneously in the same reactor,provides a new way for biological nitrogen removal and lays the foundation for simultaneous nitrification and denitrification theoretical basis of new technologies. Researcher isolated aerobic

Manuscript received April 24, 2013; revised June 14, 2013.

Hongyu Wang is with School of Civil Engineering, Wuhan University, Wuhan 430070, P. R. China (email: hywang96@126.com). denitrifier which could have nitrate respiration under aerobic conditions, and studied morphological, physiological characteristics, characteristics of the denitrification. 16s RDNA gene sequence was used for identification of isolated Strain. The DNA genes were extracted and amplified by PCR. 16S rDNA identification of bacteria is more accurate and rapid than the conventional physiological and biochemical tests.

\section{MATERIALS AND METHODS}

\section{A. Medium}

The cultural medium for isolation was composed of the following ingredients $\left(\mathrm{g}^{-1}\right)$ [Robertson 1992]: $\mathrm{Na}_{2} \mathrm{HPO}_{4} \cdot 7 \mathrm{H}_{2} \mathrm{O}, \quad 7.9 ; \quad \mathrm{KH}_{2} \mathrm{PO}_{4}, \quad 1.5 ; \quad \mathrm{NH}_{4} \mathrm{Cl}, \quad 0.3 ;$ $\mathrm{MgSO}_{4} \cdot 7 \mathrm{H}_{2} \mathrm{O}, 0.1$ and trace element solution, $2 \mathrm{ml} / \mathrm{L}$. The trace element solution was composed of the following ingredients $\left(\mathrm{g} \mathrm{L}^{-1}\right)$ : EDTA, 50.0; $\mathrm{ZnSO}_{4}, 2.2 ; \mathrm{CaCl}_{2}, 5.5$; $\mathrm{MnCl}_{2} \cdot 4 \mathrm{H}_{2} \mathrm{O}, 5.06 ; \mathrm{FeSO}_{4} \cdot 7 \mathrm{H}_{2} \mathrm{O}, 5.0 ;\left(\mathrm{NH}_{4}\right)_{6} \mathrm{Mo}_{7} \mathrm{O}_{2} \cdot 4 \mathrm{H}_{2} \mathrm{O}$, 1.1; $\mathrm{CuSO}_{4} \cdot 5 \mathrm{H}_{2} \mathrm{O}, 1.57 ; \mathrm{CoCl}_{2} \cdot 6 \mathrm{H}_{2} \mathrm{O}, 1.61 ; \mathrm{pH}=7.0$. The $\mathrm{pH}$ of the cultural medium was controlled between 7 7.5. The nitrate nitrogen level was adjusted based on the experiment requirement.

\section{B. Screening of Aerobic Denitrifiers}

The Sample containing aerobic denitrifiers from activated sludge domesticated was collected [10]. Purification and isolation of bacterial plate was carried out by using double dilution methods. The pure strain was inoculated into autoclaved $250 \mathrm{ml}$ Erlenmeyer flask containing $100 \mathrm{ml}$ of DM medium. Then some beadings were put in the Erlenmeyer flask to decrease the influence of tiny anaerobic environment on the experiment result. The mouths of the Erlenmeyer flask were bundled with nine layer of gauze. The bottles were put on a rotary shaker and incubated at $30^{\circ} \mathrm{C}$ for $24 \mathrm{~h}$ while shaking vigorously at $160 \mathrm{rpm}$. Liquid samples were taken from the bottles before and after culture to investigate the effect of the strain on the TN removal of the culture medium. 21 strains with high TN removal ability under complete aerobic condition were obtained after initial screening.

\section{Experiment Equipment}

The schematic diagram of the experimental setup is shown in Fig. 1 A 2 L Erlenmeyer flask was used as the reaction vessel. A septum was equipped on the mouth of the flask. The inlet and outlet for gas passage was each equipped with a filter with a pore size of $0.25 \mu \mathrm{m}$ to filter possible bacteria interference. The flask was put in a water bath during the experiment for the purpose to maintain a constant temperature. A magnetic stir was used to mix the 
medium in the medium during the experiment. Sampling port 1 was used for sampling nitrogen gas produced during the experiment. Sampling port 2 was used to sample water samples to monitor $\mathrm{pH}, \mathrm{DO}$, biomass, nitrate $\left(\mathrm{NO}_{3}{ }^{-}\right)$, nitrite $\left(\mathrm{NO}_{2}^{-}\right)$, and total nitrogen (TN) during the experiment. All solution and asparatus were autoclaved before put into the experiment.

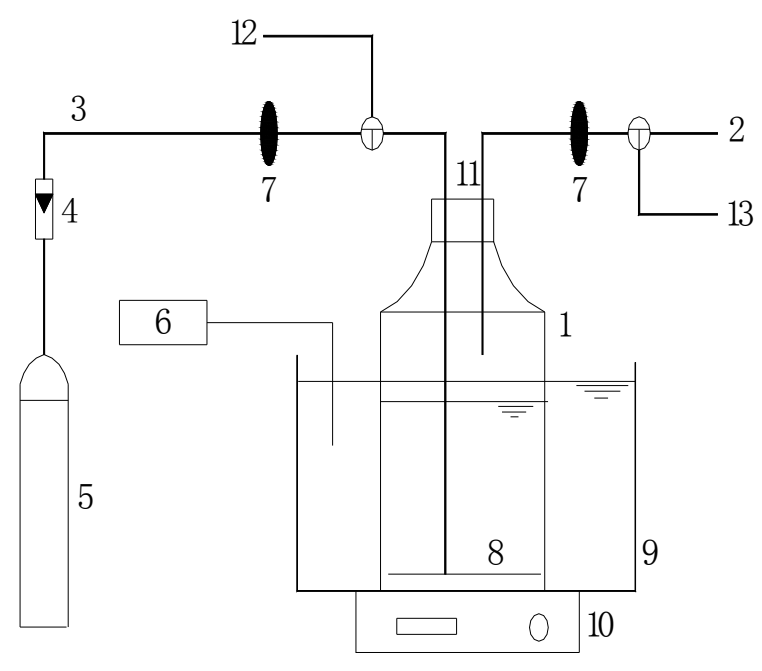

1- reactor; 2-gas outlet; 3-gas inlet; 4-gas flowmeter;5-oxygen jar; 6-temperature controller; 7-membrane filter; 8-aeration pipe; 9-waterbath; 10 - magnetic stirrer; 11 - sample port $1 ; 12$ - sample port 2; 13-barometer

Fig. 1. Schematic diagram of the experimental setup

Inoculums solution was prepared by taking one colony from an agar plate into a $100-\mathrm{ml}$ cultural medium and incubated at $30^{\circ} \mathrm{C}$ for 24 hours while shaking at $180 \mathrm{r} / \mathrm{min}$. After inoculation, pure oxygen was supplied into the medium at a rate of $0.3 \mathrm{~L} / \mathrm{min}$ to drive off the air inside the flask. After 1 hour, argon was supplied into the flask to maintain a constant pressure and prevent nitrogen gas from re-entering the flask. By doing this, aerobic condition can be maintained in the medium and nitrogen gas production due to denitrification can be quantified.

\section{Analysis}

Dissolved oxygen (DO) and water temperature were measured with an YSI DO meter (Model 5000). Oxidation-reduction potential (ORP) and $\mathrm{pH}$ were measured by a combo pH/ORP meter. Total nitrogen (TN) was measured by persulfate method as given in Standard Methods for Examination of Water and Wastewater (1998). Nitrate $\left(\mathrm{NO}_{3}{ }^{-}\right)$and nitrite $\left(\mathrm{NO}_{2}{ }^{-}\right)$were measured by an ion chromatography (DIONEX-100).Nitrogen gas $\left(\mathrm{N}_{2}\right)$ produced as a result of denitrification was measured by an Agilent HP4890D GC gas chromatography. The cell weight was represented by total suspended biomass (dried at $103-105^{\circ} \mathrm{C}$ ). To ensure the accuracy, each test was replicated during the experiment.

\section{E. Morphological Identification and Phylogenic Identification of Aerobic Denitrifier}

1) The PCR amplification and $16 \mathrm{~S} r D N A$ sequencing Amplification of $16 \mathrm{~S}$ rDNA was performed on the isolated DNA using universal bacterial $16 \mathrm{~S}$ rDNA primers
[11]: forward primer 5'-AGAGTTTGATCCTGGCTCAG-3' and reverse primer 5'-AAGGAGGTGATCCAGCCGCA-3'. The gene was amplified by PCR with 40ng of total DNA as the template. PCR was performed by 30 cycles at $94{ }^{\circ} \mathrm{C}$ for $30 \mathrm{~s}, 58{ }^{\circ} \mathrm{C}$ for $45 \mathrm{~s}, 72{ }^{\circ} \mathrm{C}$ for $1.5 \mathrm{~min}$ and followed by final extension at $72{ }^{\circ} \mathrm{C}$ for $10 \mathrm{~min}$ [12]. Amplified products were resolved on $1.0 \%$ agarose gel, then excised from the gel and purified. The DNA sequences were assembled using Autoassembler and sequence navigator. The 16S rDNA sequence was compared with the published data in GenBank by using BLAST.

\section{2) Morphological observation}

The isolated strains were observed by Transmission Electron Microscope (TEM) and regularly physiological and biochemical characteristics were determined [13].

\section{ANALYZE OF RESULTS}

\section{A. Isolation and Denitrification Characteristics of Screened Strains}

After screening, 21 strains of bacteria were isolated from the sludge and the strains exhibited high TN removal rates of more than $50 \%$. Those isolated strains were further screened for their aerobic denitrification capabilities using succinate at a $\mathrm{C} / \mathrm{N}$ ratio of 4 . Finally, 6 of those isolated strains were found having greater than $70 \%$ aerobic nitrate $\left(\mathrm{NO}_{3}-\mathrm{N}\right)$ removal. Among them $\mathrm{Z31}$ was found having the higher aerobic $\mathrm{NO}_{3}-\mathrm{N}$ removal $(80 \%$ compared to averaged $60 \%$ ). The reactor in Fig. 1 was used to verify the characteristics of aerobic denitrification. If nitrate or nitrite can be used as electron acceptor, maybe the end product of denitrification $\mathrm{N}_{2}$ or $\mathrm{N}_{2} \mathrm{O}$ was generated. By detecting the $\mathrm{NO}_{3}-\mathrm{N}, \mathrm{NO}_{2}-\mathrm{N}$ change and formation of nitrogen, strains can be determined to have aerobic denitrification capacity.

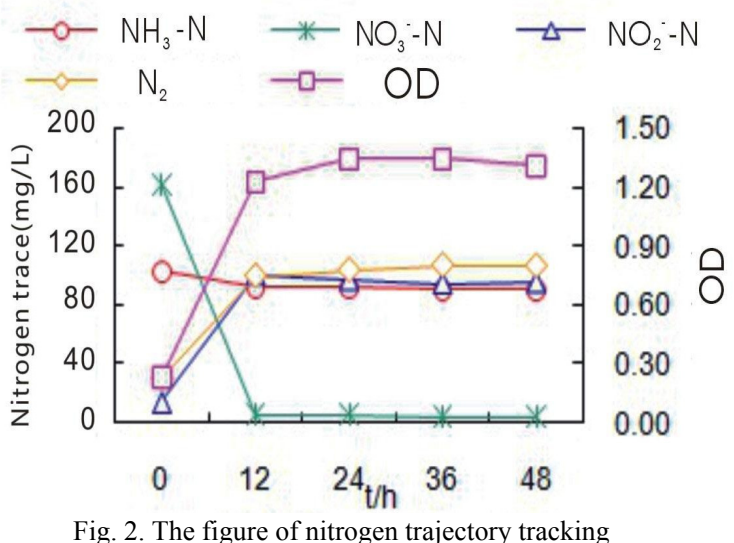

Test medium for denitrification was used. In medium, $1.2 \mathrm{~g} / \mathrm{L} \mathrm{KNO}_{3}$ of electron acceptor was added and the other components unchanged. The results were shown in Fig. 2.

It was found from Fig. 2 that the strain Z31 could show corespiration of oxygen and nitrate and simultaneous production of nitrogen gas. Dentitrification process mainly occurred in LOG phase, this was because that in the phase the growth and proliferation of bacteria was the most exuberant and the amount of its energy and reducing force needed was the maximum. 
It was observed from Fig. 2 that there was obvious nitrite accumulation during the denitrification process of the strain Z31. It can be concluded that the denitrification process of the strain was via nitrate, nitrite and nitrogen gas pathway. This might be that nitrate was reduced to nitrite under the effect of nitrate reductase in bacteria. The presence of nitrite can rapidly induce nitrite reductase, which reduces the nitrite to nitrogen.

In addition, from the Fig. 3 , it is observed that $\mathrm{pH}$ in the culture medium increased while ORP in the medium decreased during the dentirification process. The increase of $\mathrm{pH}$ may be attributed to the alkali production of denitrification process and the decrease of ORP may be caused by the result that high-oxidized nitrogen was reduced to low-oxidized nitrogen accompanying with ORP falling.

It can be drawn from the above results that the strain Z31 is able to reduce nitrate to dinitrogen gas under fully aerobic conditions, which can determine the strain Z31 is an aerobic denitrifier.

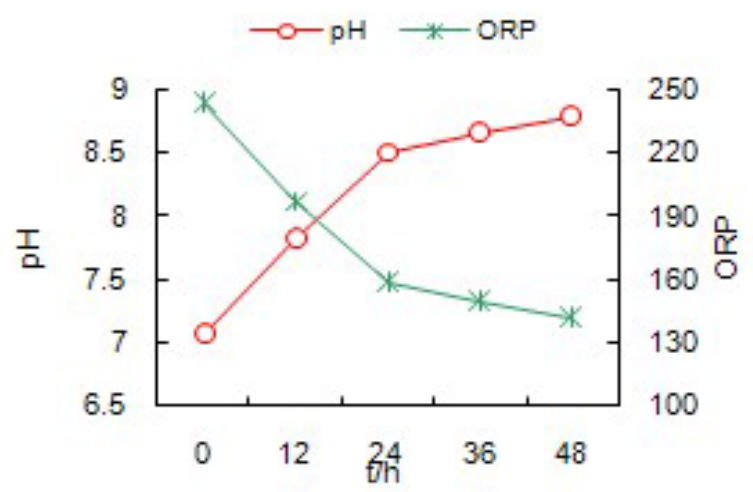

Fig. 3. $\mathrm{pH}$ and O.R.P. tracking

\section{B. Physiological and Biochemical Identification of Strain} Z31

The observed morphological and physiological characteristics are shown in Fig. 4. and Table 1. respectively. Z31 is short rod-shaped with a size of $0.5 \times 1.4 \mu \mathrm{m}$. It is gram-negative. Morphological characteristics of strain Z31 on nutrient agar were round, serrated edge, surface radial, light yellow, opaque and low convex. Experimental results showed that the optimal growth temperature of strain Z31 was $30 \sim 35^{\circ} \mathrm{C}$ and the best $\mathrm{pH}$ was $7 \sim 9$. Many kinds of carbon sources can be used by Z31, including organic acids, mannitol, glucose and starch.

\section{Identification of the $16 \mathrm{~S}$ rDNA Gene Sequence and Phylogenetic Analysis of the Strain Z31}

A part of the 16S rRNA gene sequence of the strain Z31 and nucleic acid data in GenBank were compared and analyzed by Blast program. The phylogenetic tree of Z31 is illustrated in Fig. 5. It is indicated that Z31 is in the same branch with Pseudomonas sp. and has a 99\% similarity to Pseudomonas stutzeri (P. stutzeri). According to the morphological observation, physiological biochemical test and sequence analysis of the $16 \mathrm{~S}$ rDNA, strain $\mathrm{Z} 31$ was identified as Pseudomonas stutzeri.

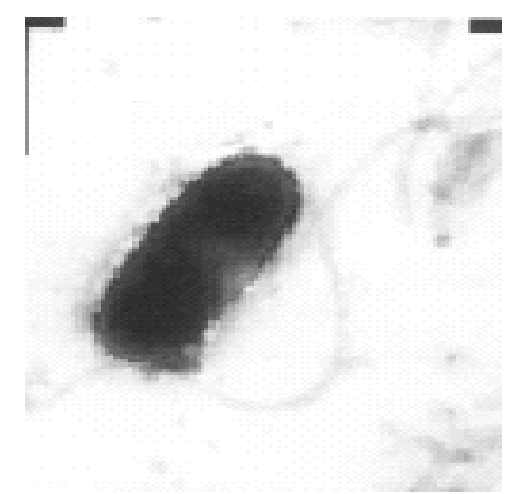

Fig. 4. TEM image of strain Z31

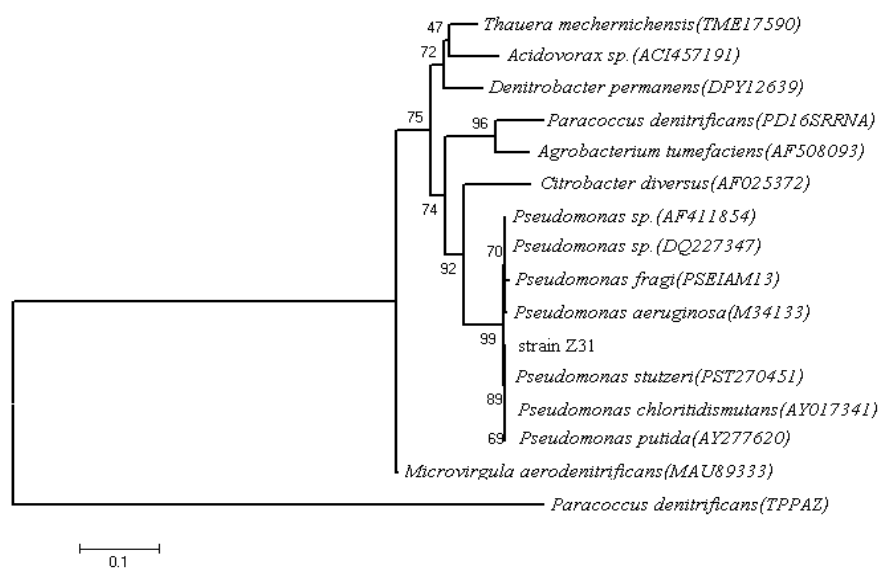

Fig. 5. Unrooted phylogenetic trees based on the partial 16S rDNA sequences of strain Z31 and related bacteria

TABLE I: BIOCHEMICAL TEST RESULTS OF STRAIN Z31

\begin{tabular}{|c|c|c|c|c|c|c|}
\hline \multicolumn{2}{|l|}{ Project } & Results & Project & Results & Project & $\begin{array}{l}\text { Resul } \\
\text { ts }\end{array}$ \\
\hline \multicolumn{2}{|c|}{ Catalase test } & + & $\begin{array}{l}\text { Starch } \\
\text { hydrol } \\
\text { ysis } \\
\text { test }\end{array}$ & + & $\begin{array}{l}\text { Citrate } \\
\text { utilizati } \\
\text { on }\end{array}$ & + \\
\hline \multicolumn{2}{|c|}{$\begin{array}{l}\text { Fermentation of } \\
\text { glucose oxidation }\end{array}$} & $\begin{array}{l}\text { Acid } \\
\text { ferment } \\
\text { ation }\end{array}$ & $\begin{array}{l}\text { Fat } \\
\text { hydrol } \\
\text { ysis } \\
\text { test }\end{array}$ & + & $\begin{array}{l}\text { Gelatin } \\
\text { liquefac } \\
\text { tion test }\end{array}$ & - \\
\hline \multirow{5}{*}{$\begin{array}{l}\text { Fermenta } \\
\text { tio-n of } \\
\text { sugar and } \\
\text { alcohol }\end{array}$} & $\begin{array}{l}\text { Gluc } \\
\text { ose }\end{array}$ & - & $\begin{array}{l}\text { Methyl } \\
\text { red test }\end{array}$ & + & $\begin{array}{l}\text { Hydrog } \\
\text { en } \\
\text { sulfide } \\
\text { product } \\
\text { ion test }\end{array}$ & + \\
\hline & $\begin{array}{l}\text { Fruct } \\
\text { ose }\end{array}$ & $\oplus$ & $\begin{array}{l}\text { Acetyl } \\
\text { methyl } \\
\text { alcohol } \\
\text { test }\end{array}$ & - & $\begin{array}{l}\text { Ammon } \\
\text { ia } \\
\text { product } \\
\text { ion test }\end{array}$ & + \\
\hline & $\begin{array}{l}\text { Lacto } \\
\text { se }\end{array}$ & - & $\begin{array}{l}\text { Indole } \\
\text { produc } \\
\text { tion } \\
\text { test }\end{array}$ & + & $\begin{array}{l}\text { Urea } \\
\text { hydroly } \\
\text { sis test }\end{array}$ & + \\
\hline & $\begin{array}{l}\text { Sucro } \\
\text { se }\end{array}$ & - & $\begin{array}{l}\text { Litmus } \\
\text { milk } \\
\text { test }\end{array}$ & $\begin{array}{l}\text { The } \\
\text { reduced } \\
\text { rennet } \\
\text { coagula } \\
\text { t-ed }\end{array}$ & $\begin{array}{l}\text { Aerobic } \\
\text { test }\end{array}$ & $\begin{array}{l}\text { Aero- } \\
\text { bic }\end{array}$ \\
\hline & $\begin{array}{l}\text { Ethan } \\
\text { ol }\end{array}$ & - & $\begin{array}{l}\text { Nitrate } \\
\text { reducti } \\
\text { on test }\end{array}$ & + & & \\
\hline
\end{tabular}

"十"= Positive,,$"$ "=Negative,,$" \circ "=$ Produce Gas, $\oplus "=$ Produce acid and gas

\section{CONCLUSION}

6 strains of bacteria with $70 \% \mathrm{TN}$ removal were isolated from the sludge after enrichment culture. The strain Z31 
with higher nitrogen removal was selected and its characteristic of aerobic denitrification was confirmed by the nitrogen element track.

According to the morphological observation, physiological biochemical test and sequence analysis of the 16S rDNA, strain Z31 was identified as Pseudomonas stutzeri.

\section{ACKNOWLEDGMENT}

This research was financially supported by the open fund of State Key Lab of Urban Water Resources and Environment (HIT) (NO. QAK201014), the National Natural Science Foundation of China (NSFC) (NO. 51008239) and State university students innovative pilot scheme (NO. 1210486055).

\section{REFERENCES}

[1] J. Sun, Nitrogenous Wastewater Treatment Technology and Application, Beijing: Chemical Industry Press, pp.15-16, 2003.

[2] L. Chen and B. Wang, Wastewate Biological Treatment Technology, Beijing: China Architecture \& Building Press, pp138-141, 2000.

[3] L. A. Robertson and J. G. Kuenen. "Aerobic denitrification: a controversy revived," Arch. Microbiol, vol. 139, pp. 351-354, 1984.

[4] L. A. Robertson, E. D. W. J. VAN Niel, ROB A. M. Torremans et al., "Simultaneous nitrification and denitrification in aerobic chemostat cultures of Thiosphaeera Pantotropha," Applied and Environmental Microbiology, vol. 54, no. 11, pp. 2812-2818, 1988.

[5] A. B. Gupta, "Thiosphaeera Pantotropha a sulphur bacterium capable of simultaneous heterotrophic nitrification and aerobic denitrification," Enzyme and Microbile Technology, vol. 21, pp. 589-595, 1997.

[6] D. Patureau, J. J. Godon, P. Dabert et al., "Microvirgula aerodenitrificans gen. nov., sp.nov.,a new gram-negative bacterium exhibiting co-respiration of oxygen and nitrogen oxides up to oxgen satured conditions," Int.J.Sys.Bacteriol, vol. 48, pp. 775-782, 1998.

[7] E. Scholten, T. Lukow, G.Auling et al., "Thaurea mechernichensis sp.Nov., an aerobic denitrifier from a leachate treatment plant," Int.J.Sys.Bacteriol, vol. 49, pp. 1045-1051, 1999.

[8] H. Zheng, Y. Liu, G. Sun, X. Gao, Q. Zhang, and Z. Liu, "Denitrification characteristics of a marine origin psychrophilic aerobicdenitrifyingbacterium," Journal of Environmental Sciences vol. 23, no. 11, pp. 1888-1893, 2011.

[9] X. Qiu, T. Wang, X. Zhong, G. Du, and J .Chen, "Screening and characterization of an aerobic nitrifying-denitrifying bacterium from activated sludge," Biotechnology and Bioprocess Engineering, vol. 17, no. 2, pp. 353-360, 2012.

[10] D. Zhou, F. Ma, H. Wang, and S. Dong. "Study on Screening Methord of Aerobic Denitrifiers," Acta Microbiologica Sinica, vol. 44, no. 6, pp. 837-839, 2004

[11] R. Devereux and S. G. Willis, "Amplification of ribosomal RNA sequences Molecular microbial ecology manual," Netherland.Kluwer Academic Publishers, pp. 1-11, 1995.

[12] G.. Damiani, P. Amedeo, C. Bandi et al., "Bacteria identification by PCR-Based Techniques," Microbial Genome Methods, C. R. C Press, Chapter 10, pp. 167-177, 1996.

[13] X. Dong and M. Cai, Identification of common bacterial system manual, Beijing: Science Press, 2001.

Hongyu Wang was born in Hubei province, China, on 1976.10.30. He is good at wastewater technology and biological nitrogen and phosphorus removal. State key laboratory of urban water resource and water environment open topic, denitrifying phosphorus accumulating bacteria separation and simultaneous nitrogen and phosphorus mechanism research, 2008-2008, the project director . National ministry of science and technology "11th five-year plan" science and technology support plan, small cities and towns of central drinking water fluoride arsenic removal technology research and equipment development, 2007-2010, the main participants. 